\title{
Pharmacognostic, Phytochemical and Physicochemical Investigations of Hypericum hookerianum Wight \& Arn. (Hypericaceae) of Palni Hills, India
}

\author{
Mahendrakumar $\mathbf{M}^{1}$, Nirmalraj $S^{1}$, Ravikumar $\mathbf{M}^{1}$, Bharath $\mathbf{B}^{1}$, Seeni $\mathrm{S}^{2}$, Perinbam $\mathrm{K}^{1}$
}

\section{Mahendrakumar $\mathrm{M}^{1}$, Nirmalraj S ${ }^{1}$, Ravikumar $M^{1}$, Bharath $B^{1}$, Seeni $S^{2}$, Perinbam K ${ }^{1}$}

${ }^{1} \mathrm{PG}$ and Research Department of Plant Biology and Plant Biotechnology, Government Arts College for Men, (Autonomous), Nandanam, Chennai, Tamil Nadu, INDIA

${ }^{2}$ School of Biosciences, Mar Athanasios College for Advanced Studies (MACFAST) Tiruvalla, Kerala, INDIA.

\section{Correspondence}

Perinbam K, PG and Research Department of Plant Biology and Plant Biotechnology, Government Arts College for Men, (Autonomous), Nandanam, Chennai, Tamil Nadu, INDIA.

Phone no: +919940867295

E-mail: drperinbam73@gmail.com

History

- Submission Date: 22-05-2017;

- Review completed: 08-06-2017;

- Accepted Date: 09-08-2017

DOI : 10.5530/pj.2017.6.118

Article Available online

http://www.phcogj.com/v9/i6

Copyright

(C) 2017 Phcog.Net. This is an openaccess article distributed under the terms of the Creative Commons Attribution 4.0 International license.

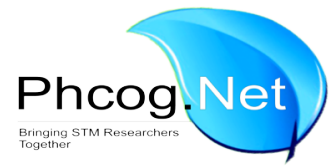

\begin{abstract}
Introduction: Hypericum hookerianum Wight and Arn. (Hooker's wort) is a lesser known unfamiliar yet critically endangered native therapeutically active native medicinal plant. It is being characterized by the presence of various secretory glands. Methodology: In this present study, characterization of the plant in terms of morphology, anatomy and histochemistry of tissues and phytochemicals and antimicrobial potentials were made. Results: The epidermal layer contains oil cells while histochemistry showed the presence of the secondary metabolites. Qualitative analysis indicated presence of maximum phytocompounds in the high polar ethanolic extract; flavonoids, anthocyanin and phenol are prominently present and quantified. Conclusion: The results suggest that the less studied herb, $H$. hookerianum is a multifaceted high value species having a wide range of phytochemicals with abundant medicinal properties.

Key words: Hypericum hookerianum, Pharmacognosy, Physiochemistry, Palni Hills.
\end{abstract}

\section{INTRODUCTION}

Hypericum is a large genus of herbs, shrubs and sometimes trees comprising 490 species of 36 sections. ${ }^{1}$ They represent a large pool of natural resource for phytochemical, pharmacological and product development investigations as they accumulate pharmacologically important secondary metabolites. Many of the species contain structurally and functionally diverse phenolics, flavonoids and therapeutically important phenolic derivatives the dianthrone, hypericins and the prenylated phloroglucinol, hyperforin. The highest levels of the chemicals are found at full flowering stage when almost all the plants of the genus are widely used in folk medicine in different parts of the world. The growing interest in the usage of Hypericum in traditional medicine is due to several reasons the principal one being that modern medicine has invariably side effects and its costs are prohibitive. Among an estimated 27 species reported from India including the most popular and productized, H.perforatum and the recently investigated $H$. hookerianum, a high altitude shrub of the Himalayas and the Western Ghats. Hypericum hookerianum Wight and Arn. Also known as Norysca hookeriana Wight and Arn. commonly known in Nepal as Mehandiphul, is a round topped shrub with weakly spreading, non-erect branches with golden-yellow flowers also distributed in Sikkim, Khasiand Jaintia hills of Himalayas and in the high altitudes $(>2300 \mathrm{~m})$ of the Nilgiris and Palni hills of the Western Ghats. ${ }^{2}$ The terete shrubs are $2-2.5 \mathrm{~m}$ in height, with rather flaccid ovate leaves, set bifarious, mucronate to mucronate at apex. ${ }^{2}$ The tribal people of the Shola forest (Tamil Nadu) in Palni hills use the aerial parts of the plant for treating burns and wounds demonstrated by Mukherjee and Suresh. ${ }^{3}$ to have wound healing properties. The Toda tribe of the Palni hills uses it as a folklore medicine for its different therapeutic potentials, including antidepressant, spasmolytic, stimulant, hypotensive and antifungalactivities. ${ }^{4}$ Leaf anatomy of hypericum species differ greatly and is the basis for not only identifying the species but also grouping them under different taxonomic criteria. Anatomical features in terms of types of glands present, secretions of the glands, interconnecting and extension of the ducts, quality of the products of the secretory glands and phytochemical profiles of the secretion play an important in differentiating the species. The anatomy and ultra-structure of the cavities in the internodes, leaves and petals varied extensively between species of Hypericum, especially in $H$. hookerianum. The secondary growth is more extensive in shrubs (H. inodorum and $H$. forestii). The petals also differ between species in the mesophyll structures and the occurrence and location of secondary structures. ${ }^{5}$ It is against this background, the pharmacognostic profile, anatomy of the secretory 
structures, phytochemical constituents, anti-bacterial activity of H. hookerianum were studied.

\section{MATERIAL AND METHODS}

\section{Collection and authentication of the plant}

Leaves of H. hookerianum were collected from Pambar Shola forest in the outskirts of Kodaikanal Town of Palni hills in the Western Ghats of Indian the month of June, 2015 (Figure. 1). The taxonomical identification of the plant was authenticated by Prof P. Jayaraman, Institute of Herbal Science, Plant Anatomy Research Centre, Chennai, Tamil Nadu. The voucher specimen (voucher no. CNBT/15/HH/01) was preserved in our laboratory for future reference.

\section{Reagent and Chemicals}

All the chemicals and reagents used were of analytical grade, purchased from Sigma chemical co. (St Louis, MQ, USA) and Merck (Darmstadt, Germany).

\section{Macroscopic Investigation}

For morphological observations, fresh leaf approx. 3-5 cm in length was used. The macro-morphological characteristics of the leaf were observed under magnifying lens. ${ }^{6}$

\section{Pharmacognostic studies}

Pharmacognostic studies include organoleptic characters and microscopical features of the plant.

\section{Morphological investigation}

The morphology evaluation is used to find the closely related species and used to study the external texture and sensory characters such as color, odor, taste, size, shape etc. Fresh leaves of H.hookerianum were used for the morphological studies and reported. ${ }^{7,8}$

\section{Microscopical investigation of fresh leaf and dried powder}

The transverse and longitudinal sections of the fresh leaves were prepared using standard procedures. ${ }^{9}$ The normal leaf samples of $H$. hookerianum were cut and detached from the plant and fixed in F.A.A. (Formalin $5 \mathrm{ml}+$ Acetic acid $-5 \mathrm{ml}+70 \%$ Ethyl alcohol $-90 \mathrm{ml})$.After $24 \mathrm{hrs}$ of fixing, the specimens were dehydrated with a graded series of tertiary-Butyl alcohol as per the schedule given by Sass. ${ }^{10}$ Infiltration of the specimens was carried by gradual addition of paraffin wax (melting point $58-60^{\circ} \mathrm{C}$ ) until TBA solution attained super saturation. The specimens were cast into paraffin blocks. The paraffin embedded specimens were sectioned with the help of Rotary Microtome. The thickness of the sections was 10-12 $\mu \mathrm{m}$. Dewaxing of the sections was by customary procedure. ${ }^{11}$ The sections were stained with Toluidine blue as per the method published by O'Brien et al.. ${ }^{12}$ Since Toluidine blue is a polychromatic stain. The staining results were remarkably good; and some cytochemical reactions were also obtained. The dye rendered pink color to the cellulose walls, blue to the lignified cells, dark green to suberin, violet to the mucilage, blue to the protein bodies, etc. Wherever necessary sections were also stained with safranin and Fast-green and IKI. For studying the stomatal morphology, venation pattern and trichome distribution, paradermal sections as well as clearing of leaf with $5 \% \mathrm{NaOH}$ or epidermal peeling by partial maceration employing Jeffrey's maceration fluid. ${ }^{10}$ were prepared. Glycerine mounted preparations were made and the different cell components were studied and measured. The dried powdered material of leaf was used to evaluate the powder analysis following the method of Brian and Turner. ${ }^{7}$

\section{Photomicrographs}

Microscopic descriptions of tissues are supplemented with micrographs wherever necessary. Photographs of different magnifications were taken with Nikon LabPhoto 2 microscopic Unit. For normal observations, bright field was used. For the study of crystals, starch grains and lignified cells, polarized light was employed. Since these structures have birefringent property, under polarized light they appear bright against dark background. Magnifications of the figures are indicated by the scale-bars. Descriptive terms of the anatomical features are as given in the standard anatomy book. ${ }^{13}$

\section{Fluorescence Evaluation}

The fluorescence analysis of the dried leaf powder was carried out by the method of Kokoski et al. ${ }^{14} \mathrm{~A}$ small quantity of the sample treated using fluorescence reagents (such as $1 \mathrm{~N} \mathrm{NaOH}, 1 \mathrm{~N} \mathrm{HCl}, 50 \% \mathrm{H}_{2} \mathrm{SO}_{4}, \mathrm{FeCl}_{3}$, Iodine Solution, Acetic Acid Glacial, 0.1 $\mathrm{N} \mathrm{NH}_{4} \mathrm{OH}, 1 \% \mathrm{CH}_{3} \mathrm{COOH}$ ) and analyzed under visible light and ultra violet light (Wavelength $254 \mathrm{~nm}$ ).

\section{Phytochemical determination}

The dried leaf powder of $H$. hookerianum was extracted successively with different polarity solvents such as Hexane, Ethyl Acetate and Ethanol. After 24 hours, the dried extracts were obtained and were analyzed using chemical reagents for both qualitative phytochemical evaluation following standard procedure. ${ }^{15}$

\section{Estimation of total phenol, anthocyanin and flavonoid}

The Folin-Ciocalteu method was used to determine total phenolic content (TPC) of the various solvent extracts as described by Singleton and Rossi. ${ }^{16}$ Gallic acid was used as a reference standard $(20-100 \mu \mathrm{g} / \mathrm{mL})$ for plotting calibration curve. A volume of $0.5 \mathrm{~mL}$ of the plant extract $(100 \mu \mathrm{g} / \mathrm{mL})$ was mixed with $1.5 \mathrm{~mL}$ of Folin-Ciocalteu reagent (diluted 1:10with de-ionized water) and were neutralized with $3 \mathrm{~mL}$ of sodium carbonate solution $(7.5 \%, \mathrm{w} / \mathrm{v})$. The reaction mixture was kept in dark at room temperature for $30 \mathrm{~min}$ with intermittent shaking for color development. The absorbance of the resulting blue color was measured by using double beam UV-Vis spectrophotometer at fixed wavelength of $765 \mathrm{~nm}$. The TPCs were determined using linear regression equation obtained from the standard plot of gallic acid. The content of total phenolic compounds was calculated as mean $\pm S D(n=3)$ and expressed as $\mathrm{mg} / \mathrm{g}$ gallic acid equivalent (GAE) of dry extract.

Total anthocyanin content of the extract was determined by the $\mathrm{pH}$ differential method. ${ }^{17} \mathrm{~A} \mathrm{pH} 1.0$ buffer solution was prepared by mixing $125 \mathrm{ml}$ of $0.2 \mathrm{~N} \mathrm{KCl}$ with $385 \mathrm{ml}$ of $0.2 \mathrm{~N} \mathrm{HCl}$ and $490 \mathrm{ml}$ of distilled water. The $\mathrm{pH}$ of the buffer was adjusted to $\mathrm{pH} 1.0$ with $0.2 \mathrm{~N} \mathrm{HCl}$. A pH 4.5 buffer solution was also prepared by mixing $440 \mathrm{ml}$ of $1.0 \mathrm{M}$ sodium acetate with $200 \mathrm{ml}$ of $1 \mathrm{M} \mathrm{HCl}$ and $360 \mathrm{ml}$ of distilled water. The $\mathrm{pH}$ of the solution was measured and adjusted topH 4.5 with $1 \mathrm{M} \mathrm{HCl}$. The sample extract $(0.5 \mathrm{ml})$ was diluted to $12.5 \mathrm{ml}$ in the $\mathrm{pH} 1.0$ and 4.5 buffers and allowed to equilibrate in the dark for $2 \mathrm{~h}$. The absorbance of the samples at $512 \mathrm{~nm}\left(\mathrm{~A}_{512} \mathrm{~nm}\right)$ and $700 \mathrm{~nm}\left(\mathrm{~A}_{700} \mathrm{~nm}\right)$ was measured. The difference in absorbance $(\Delta \mathrm{A})$ between the anthocyanin extract diluted in $\mathrm{pH} 1.0$ and $\mathrm{pH} 4.5$ buffers was calculated and total anthocyanin content was also estimated.

The total flavonoid content (TFC) of each extract was investigated using the aluminum chloride colorimetry method. ${ }^{18}$ The calibration curve was prepared by diluting quercetin in $95 \%$ ethanol $(0-100 \mu \mathrm{g} / \mathrm{mL})$. The diluted extract or quercetin $(2.0 \mathrm{~mL})$ was mixed with $0.1 \mathrm{~mL}$ of $10 \%(\mathrm{w} / \mathrm{v})$ aluminum chloride solution and $0.1 \mathrm{~mL}$ of $0.1 \mathrm{mM}$ potassium acetate and $2.8 \mathrm{~mL}$ of distilled water in a test tube. The mixture was kept at room temperature for 30 minutes to complete the reaction. Then the maximum absorbance of the mixture was measured at $415 \mathrm{~nm}$ with double beam 
UV-Vis spectrophotometer against blank. A typical blank solution contained all reagents except aluminum chloride which is replaced by the same amount of distilled water. The amount of flavonoid was calculated from linear regression equation obtained from the quercetin calibration curve. TFC was expressed as $\mathrm{mg} / \mathrm{g}$ quercetin equivalent (QE) of dry extract. All the values were expressed on dried weight basis and each value represents mean $\pm S D(n=3)$.

\section{Physicochemical parameters}

The proximate analysis to assess the physicochemical parameters like total ash value, loss on drying and water soluble extractive values, $\mathrm{pH}$ value, solubility, etc. were determined as per WHO guidelines. ${ }^{19}$

\section{Antibacterial activity}

The plant extracts were analyzed for their antibacterial activity against selected human pathogens including P. vulgaris (MTCC - 426), E. coli (MTCC - 443), B. subtilis (MTCC - 441) and M.lutens (MTCC - 1538). In this method, discs of $4 \mathrm{~mm}$ were loaded with different solvent extracts of $H$. hookerianum. The discs were placed on the solidified Mueller Hinton Agar (MHA) plates spread with test bacterial strains to which the sensitivity was measured (Figure. 3). The plates were incubated at $37^{\circ} \mathrm{C}$ for $24 \mathrm{~h}$ and after incubation the zones of inhibition were measured. ${ }^{20}$

\section{Statistical analysis}

All experiments were repeated at least three times. Results are reported as Mean \pm S.E.M. (Standard Error of Mean).

\section{RESULTS}

\section{Macroscopical investigation}

The classification of this plant through the process of identification was done at the Institute of Herbal Science, Plant Anatomy Research Centre, Chennai, and Tamil Nadu as follows:

\section{Description of plant:}

Family : Hypericaceae

Genus : Hypericum

Species : hookerianum(Wight\&Arn.)

Synonym : Norysca hookeriana (Wight \& Arn.)

Leaves are simple alternate stipulate and petiolate. Leaves with petiole 1-4 $\mathrm{mm}$; blade narrowly lanceolate to oblong-lanceolate or broadly ovate, main lateral veins 2,3 or 4 paired, apex acute to rounded with entire margin. Inflorescence 1-5 flowered, nearly round-topped, Pedicels 3-16 $\mathrm{mm}$. The leaves are dark to light greenish in colour with slight odour and characteristic in taste, size width : $2.5-3.5 \mathrm{~cm}$ and Length : $3.5-5.5 \mathrm{~cm}$ (Table 1$)$

\section{Microscopical investigation of the fresh and dried powder}

Leaf: The transverse section of the leaf found that the presence of anamocytic stomata, epidermal cells often contain oil cells, guard cell with many chloroplast in lower epidermis and absence of stomata in upper epidermis. Palisade cells are arranged to sub adjacent to upper epidermis with very long cells, in midrib upper surface consists of one layered epidermal cells, cuticles are colored, collenchymatous are less greenish with less contents and innermost colorless. Xylem vessels are radially arranged, phloem cells are arranged with more dark contents. The leaf consists of a planoconvex midrib and thick smooth lamina. The midrib is flat on the adaxial side and conically thick on the abaxial side. The midrib is $750 \mu \mathrm{m}$ thick and $700 \mu \mathrm{m}$ wide (Figure. 2.1).The epidermal layer of the

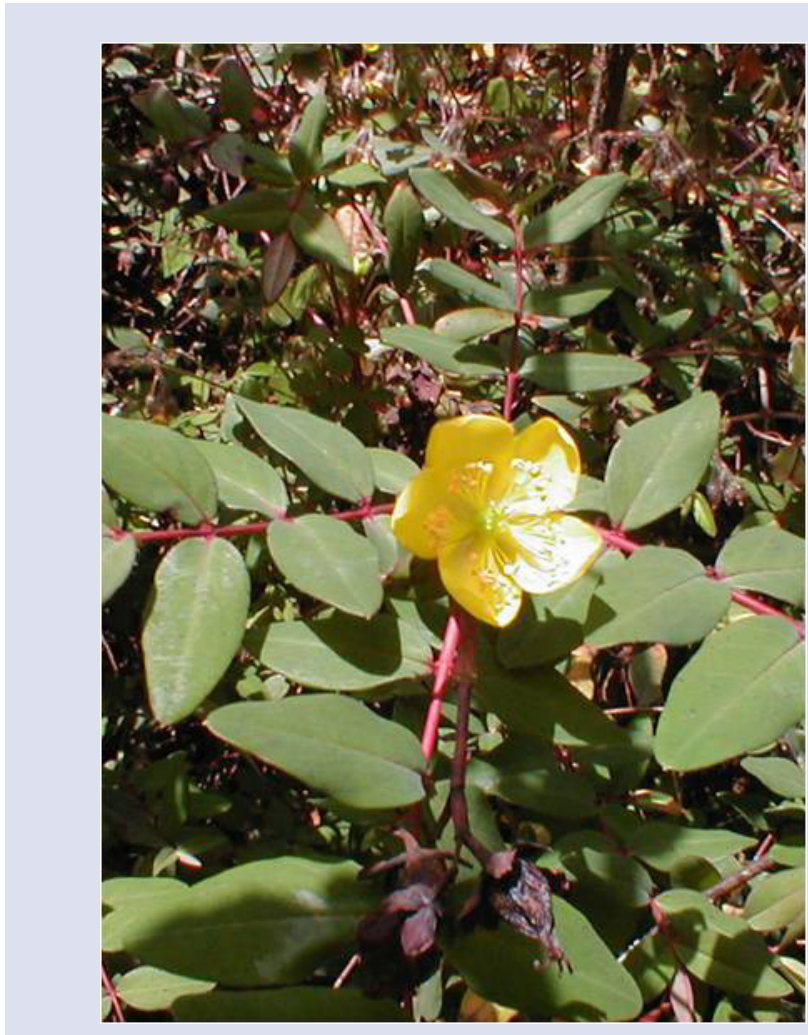

Figure 1: Habitat of Hypericum hookerianum

midrib is thin with even outer periclinal walls. The epidermal cells are squarish with thick walls. The ground tissue of the abaxial conical part consists of large, polygonal thick walled and compact. The palisade cells are extended up to the lateral parts of the adaxial region of the midrib (Figure 2.2)

The vascular bundle of the midrib is single and collateral. It consists of horizontally extended thick segment of several vertical rows of xylem elements. The xylem elements are narrow, thick walled and elliptical in outline. The abaxial part of the xylem segment bears thick walled arc of phloem elements. The phloem cells are small, thick walled and darkly stained. A thick cup shaped sclerenchymatous sheath is located on the lower end of the phloem (Figure 2.2)

Lamina (Figure 2.3): The lamina has distinct adaxial and abaxial sides. It is $320 \mu \mathrm{m}$ thick. The adaxial epidermis is thin and smooth; the cells are squarish and have thick walls. The abaxial epidermis consists of hemispherical outer tangential walls and the cells appear prominently papillate. The mesophyll tissue is differentiated into adaxial layer of single row of palisade cells and abaxial zone of about seven layers lobed spongy parenchyma cells. The spongy mesophyll forms reticulate partitions and wide air-chambers. There are wide circular secretory cavities. (Figure 2.4).

\section{Epidermal cells and stomatal morphology}

The epidermal structure was studied from the paradermal sections of the lamina. The adaxial epidermis is apostolates; the cells are rectangular to polyhedral and have thick straight anticlinal walls. The abaxial epidermis is stomatic ferous (Figure 2.5). The epidermal cells small, polygonal and have slightly wavy ad thick walls. The stomata are thick and elliptical with narrow stomatal aperture. The stomata are actinocytic type. The guard cells are surrounded by six or more radiating rectangular subsidiary cells. In surface view the stomatal complex appear star shaped (Figure 2.6). 

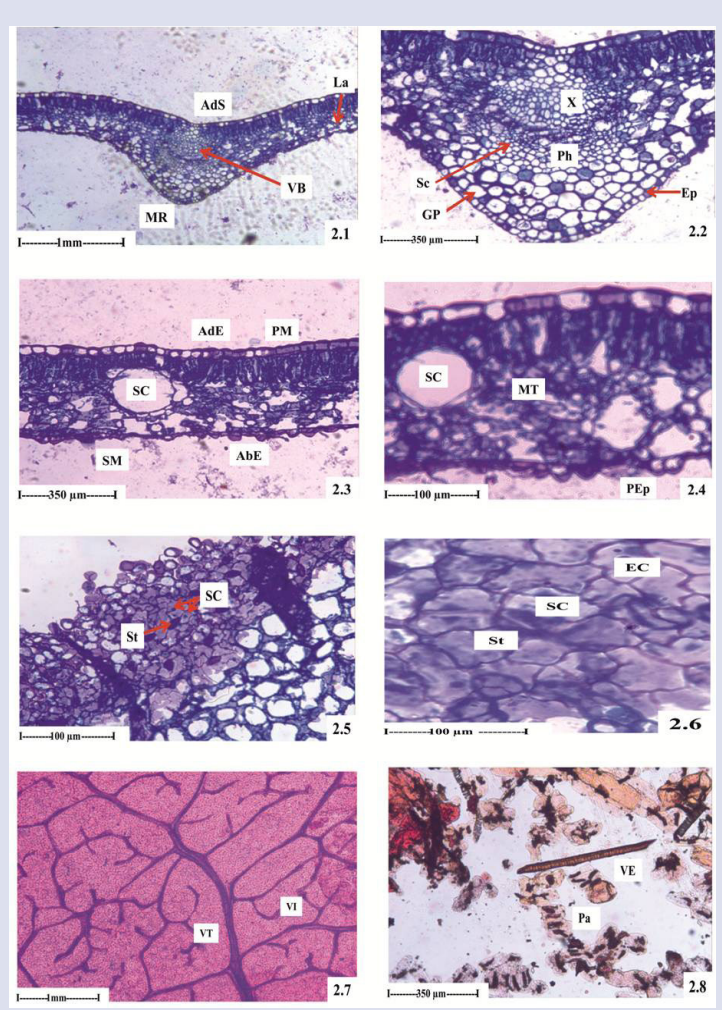

Figure 2: Pharmacognostic investigation of $\mathrm{H}$. hookerianum leaves 2.1. T.S. of leaf through midrib; 2.2. T.S. of Midrib enlarged; 2.3 \& 2.4: T.S. of Lamina; 2.5 Abaxial Epidermis; 2.6: Stomata enlarged; 2.7: Venation pattern; 2.8: Vessel Element in the powder

Note: AdS:- Adaxial Side; La : Lamina; MR : Midrib; VB : Vascular Bundles, EP: Epidermis; GP : Ground Parenchyma; Sc : Sclerenchyma; X : XylemPh : Phloem, AbE : Abaxial Epidermis; AdE : Adaxial Epidermis; Mesophyll Tissue; PEp : Papillate Epidermal Cells; PM : Palisade Mesophyll; SM : Spongy Mesophyll; SC : Secretory Cavity, SC: Subsidiary Cells; St : Stomata, EC: Epidermal Cells; VI : Vein Islets; VT : Vein Terminations; Pa : Parenchyma Cells; VE : Vessel Elements

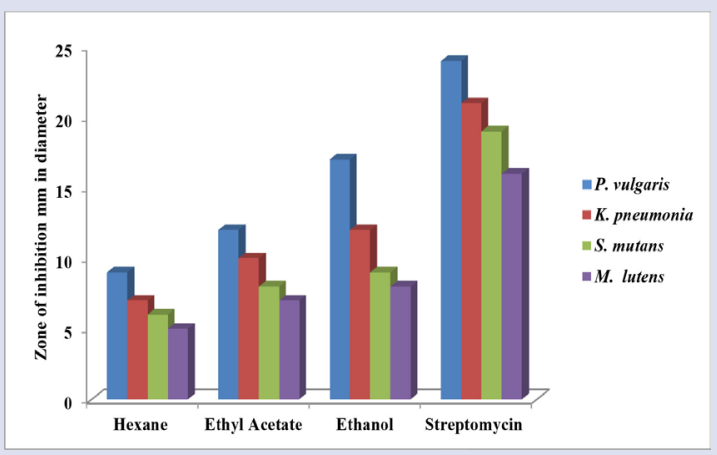

Figure 3: Antibacterial activity of different solvent extracts of leaves of $H$. hookerianum against human pathogens

\section{Venation pattern:}

The venation is densely reticulate; the thickness of the vein is gradually reduced from primary veins to secondary and tertiary veins. The vein-islets are wide and polygonal in outline. The vein boundaries are thick and straight. The vein boundaries are thick and straight. The vein terminations are short and simple (unbranched) or repeatedly branched to form dendroid outline (Figure. 2.7).

\section{Powder characteristics}

The powder preparation of the plant exhibits the following inclusions, i) Fragments of small epidermal peelings are common in the powder. The epidermal peelings are usually adaxial epidermis. The epidermal cells are polygonal in outline and their anticlinal walls are straight. The cells possess prominent nuclei and Vessel elements (Figure. 2.8) Thin, long, cylindrical vessel elements are occasionally dense bordered pits and oblique narrow end wall perferatious. The vessel elements are up to $470 \mu \mathrm{m}$ long and $40 \mu \mathrm{m}$ thick.

\section{Fluorescence Evaluation}

The fluorescence analysis is adequately susceptible and enables the precise and accurate determination of the analyte over a pleasing concentration range without several time-consuming dilution steps prior to analysis of pharmaceutical samples. ${ }^{21}$ The fluorescence analysis of the powdered leaves of $H$. hookerianum is presented in the Table 1 .

\section{Phytochemical Determination}

The phytochemical evaluation of the different solvent extracts of the leaves of $H$. hookerianum showed the presence of various phytochemical constituents which contribute to the medicinal activity of the plant listed in Table 2. The presence of various bioactive compounds justifies it might be utilized for the development of traditional medicines and further investigation is needed to elute novel active compounds from the medicinal plants which may create a new way to treat many incurable diseases.

\section{Phenolic, anthocyanin and flavonoid contents}

The total phenolic content, total anthocyanin content and total flavonoid content of the ethanolic leaf extract, calculated from the calibration curves were $14.15 \pm 0.43$ gallic acid equivalents/g, $13.59 \pm 0.45$ cyanidin equivalent/g and $28 \pm 1.37$ quercetin equivalent/g respectively (Table 3 ). Phenolic compounds have redox properties, which allow them to act as antioxidants. As their free radical scavenging ability is facilitated by their hydroxyl groups, the total phenolic concentration could be used as a basis for rapid screening of antioxidant activity. Flavonoids, including flavones, flavanols and condensed tannins, are plant secondary metabolites, the antioxidant activity of which depends on the presence of free $\mathrm{OH}$ groups, especially 3-OH.

Among three organic extracts, maximum amount of phenol, anthocyanin and flavonoid content were found in ethanol followed by ethyl acetate and hexane extracts.

\section{Physicochemical Parameters}

The proximate analysis to assess the physicochemical parameters like total ash value, loss on drying and water soluble extractive values, $\mathrm{pH}$ value, solubility, etc. The percentage yield $(\% \mathrm{w} / \mathrm{w})$ with color and consistency are mentioned in Table 4.

\section{Antibacterial activity}

Among the different solvent extracts of $H$. hookeranium leaves tested for antibacterial activity, ethanol extract showed better activity when compared to other solvent extracts. Proteus vulgaris showed highly sensitive to plant extract followed by M. luteus, B. subtilis and E.coli. 
Table 1: Fluorescence analysis of powder of $H$. hookerianum Wight \& Arn. (Leaf) with various chemical reagents

\begin{tabular}{ccc} 
Reagents & $\begin{array}{c}\text { Color observed under Visible } \\
\text { Light }\end{array}$ & $\begin{array}{c}\text { Color observed under UV Light } \\
(254 \mathrm{~nm})\end{array}$ \\
\hline Powder as such & Green & No Changes \\
Powder + Concentrated HCL & No Changes & Pale Brown \\
Powder + Concentrated $\mathrm{HNO}_{3}$ & No Changes & No Changes \\
Powder + Concentrated $\mathrm{H}_{2} \mathrm{SO}_{4}$ & Reddish & Colorless \\
Powder + Glacial acetic acid & Dark Green & Pale Green \\
Powder $+5 \% \mathrm{NaOH}$ solution & No Changes & Yellowish Green \\
Powder $+5 \% \mathrm{KOH}$ solution & No Changes & Colorless \\
Powder $+5 \%$ Ferric chloride solution & Black & Brown \\
Powder + Picric acid & Greenish Yellow & Colorless \\
Powder + Ammonia & No Changes & Pale green \\
\hline
\end{tabular}

Table 2: Qualitative analysis of phytochemicals present in different polarity solvents of leaf extracts H. hookerianum Wight \& Arn.

\begin{tabular}{cccc}
\hline $\begin{array}{c}\text { Phytochemical } \\
\text { tests }\end{array}$ & Hexane & Ethyl Acetate & Ethanol \\
\hline Alkaloids & + & + & ++ \\
Anthroquinones & - & - & + \\
Flavonoids & + & ++ & ++ \\
Glycosides & - & + & + \\
Phenols & - & ++ & ++ \\
Saponins & - & + & + \\
Steroids & + & + & + \\
Tannins & - & + & + \\
Terpenoids & - & + & + \\
\hline
\end{tabular}

$(++)$ : Present in high concentration, (+) : Present in moderate concentration and (-) : Absent

Table 3 : Quantitative analysis of phytochemicals present in different polarity solvents of leaf extracts of H. hookerianum Wight \& Arn.

\begin{tabular}{cccc}
\hline Bioactive compounds & Hexane & Ethyl Acetate & Ethanol \\
\hline Phenol & $9.14 \pm 0.33$ & $12.33 \pm 0.25$ & $14.15 \pm 0.43$ \\
Anthocyanin & $8.65 \pm 0.05$ & $11.18 \pm .038$ & $13.59 \pm 0.45$ \\
Flavonoids & $19.47 \pm 1.21$ & $23.28 \pm 0.14$ & $28.47 \pm 1.37$ \\
\hline
\end{tabular}

Total phenolics: mg of GAE/g of dry extract; Total anthocyanins : mg of Cyanidin 3-glucoside /g of dry extract, Total flavonoids: $\mathrm{mg}$ of $\mathrm{QE} / \mathrm{g}$ of dry extract; All the values are given means of triplicates determinations. Data presented as the Mean \pm SD.

Table 4: Physico-chemical parameters of the leaves of $\boldsymbol{H}$. hookerianum Wight \& Arn.

\begin{tabular}{lc}
\hline \multicolumn{1}{c}{ Parameter } & Values $(\% \mathrm{w} / \mathrm{w})$ \\
\hline Loss on Drying & $7.86 \pm 0.34$ \\
Ash Values & \\
Total Ash & $8.70 \pm 0.705$ \\
Acid insoluble ash & $2.80 \pm 0.037$ \\
Water soluble ash & $2.30 \pm 0.242$ \\
Extractive Values & \\
Water soluble extractive & $18.0 \pm 0.526$ \\
Methanol soluble extractive & $22.8 \pm 0.921$ \\
Dichloromethane soluble extractive & $1.50 \pm 0.049$ \\
\hline
\end{tabular}

Standard deviation $(\mathrm{SD})= \pm \mathrm{SD}$; Number of readings $(\mathrm{N})=3$ 


\section{DISCUSSION}

Plants possess contain numerous phytochemical constituents, many of which are known to be biologically active compounds and are responsible for exhibiting diverse pharmacological activities. ${ }^{22}$ According to the previous records of pharmacognosy sciences plants have been used in native medicinal systems globally. Medicinal plant based research are rapidly increasing worldwide and further study with emphasis on efficiency, safety and quality of plant secondary metabolites is the need of the hour. ${ }^{9}$ Macroscopic characters involve size, arrangement, venation, texture, surface characters, markings and hardness of the plant materials. The microscopical studies (anatomical and histochemical) are often necessary to establish the botanical identity of commercial samples of medicinal plants and may play an important part in checking adulteration and substitution. It involves longitudinal and transverse sectional views of the leaves of the plant. ${ }^{23}$

The leaves of $H$. hookerianum is characterized by the presence of different types of internal secretory oil cells present in the epidermal region. The lamina of the leaves has prominent wide circular secretory cavities responsible for secretion of secondary metabolites. The bioactive secondary metabolites have been shown to decrease the risk and development of many human diseases through various biological mechanisms. The results of preliminary chemical testing confirmed thepresence of various classes of bioactive chemical constituents in ethanolic extract of H. hookerianum leaves including phenols, flavonoids, anthocyanin's, steroids, alkaloids, anthroquinones, glycosides and terpenoids. Therefore, based on the quantitative phytochemical analysis results, the total phenolic and flavonoid contents of different extracts of $H$. hookerianum leaves were estimated. The ethanol extract, was found to contain the highest content of total phenol $(14.15 \mathrm{mg} / \mathrm{g})$, anthocyanin $(13.59 \mathrm{mg} / \mathrm{g})$ and flavonoid $(28.47 \mathrm{mg} / \mathrm{g})$ as compared to hexane/ethyl acetate extracts (9.14/8.65/19.47 $\mathrm{mg} / \mathrm{g}$ and 12.33/11.18/23.28 $\mathrm{mg} / \mathrm{g}$, respectively). The physicochemical evaluation using percentage yield (w/w) color and consistency parameters is useful in the identification and authentication of crude extract. The antibacterial investigation revealed the potency of active principles in each extract which may be attributed to the high content of flavonoids, which have been reported to be involved in inhibition of nucleic acid biosynthesis and other metabolic processes. ${ }^{24}$ The present study is a preliminary data for further studies. Moreover, this data was first time reported from this high altitude plant of Palni Hills, Western Ghats of India.

\section{CONCLUSION}

Pharmacognostic, phytochemical, physicochemical investigation were carried out for the first time in the high altitudes $(>2300 \mathrm{M})$ plant of the Palni Hills, $H$. hookerianum and the results were computed to predict the utility of the species to treat common human values. The macroscopical, anatomical and powder microscopical studies provides the basis for further identification and to lay down standards for leaves. The preliminary phytochemical screening of the solvent extracts reveals the presence of flavonoids, anthocyanins, phenols, etc. The results suggest that, H.hookerianum is found a prospective versatile high value species having a wide range of phytochemicals with immense medicinal properties. Further exploration may reveal many novel features and its extraction may bring out novel products of specialized kind which needs to be upgraded / popularized before the remaining species disappear from the face of the Earth.

\section{ACKNOWLEDGEMENT}

We thank The Principal, Government Arts College for Men (Autonomous) Nandanam, Chennai - 600035 for the support and laboratory facilities provided. We are also gratefully acknowledge the help rendered by Dr. P. Jayaraman, Institute of Herbal Science, PARC, and Chennai for helping us in carrying out the anatomical studies.

\section{CONFLICT OF INTEREST}

We declare that we have no conflict of interest.

\section{ABBREVIATION USED}

$\boldsymbol{\mu g} / \mathbf{m l}$ : Micrograms per milliliter; w/v: Weight per volume; nm: Nanometer.

\section{REFERENCES}

1. Crockett GP and Robson PW. The concept of stress and stress system disorders. Overview of physical and behavioral homeostasis. J. A. M. A. $2011 ; 267(9): 1244-52$.

2. Anonymous. The wealth of India. New Delhi, India, Vol. 5, p. 273; 1962.

3. Mukharjee SK, Suresh G. Differential effect of a poly herbal formulation-OB$200 \mathrm{G}$ in male and female mice subjected to forced swim stress. Indian J. Physiol. Pharmacol. 2000; 44(3): 281-89.

4. Asolkar LV, Kakkar KK, Chakre O. Publication and information directorate. New Delhi, Vol. 1, p. 138;1992.

5. ŁOTOCKA B, OSINSKA E. Shoot anatomy and secretory structures in Hypericum species (Hypericaceae). Botanical Journal of the Linnean Society. 2010;163(1):70-86

6. Tyler V, Brady L, Robbers J. Pharmacognosy, Varghese Company, India, p. 103-141;1977

7. Brian KR, Turner TD. The practical evaluation of phyto pharmaceuticals. Edn 81. Wright Sciencetechnica, Bristol, 4-9;1975.

8. Evans WC. Trease and Evans pharmacognosy. Edn 15. Saunders Ltd, London, 545-47;2003.

9. Ahmad I, Ambarwati NSS, Arifuddin M, Rijai L, Mun'im A. Pharmacognostic and Cytotoxicity Evaluation of Indonesia Native Plant of Piper acre Blume Leaves (Piperaceae). Pharmacogn J. 2017;9(3):400-04

10. Sass JE. Elements of Botanical Microtechnique. McGraw Hill Book Co; New York.pp.222;1940.

11. Johansen DA. Plant Microtechnique. McGraw Hill Book Co; New York Pp.523;1940.

12. O'brien TP, Feder N, McCully ME. Polychromatic staining of plant cell walls by toluidine blue O. Protoplasma. 1964;59(2):368-73.

13. Easu K. Plant Anatomy John Wiley and sons. New York. Pp.767;1964

14. Kokoshi CJ, Kokoshi RJ, Slama FJ. Fluorescence of powdered vegetable Drug under UV Radiation. Sci. Ed. J. Am. Pharm. Associ. 1958;48(10):715-7.

15. Harborne JB. Phytochemical methods. 2nd Ed. London: Chapman \& Hall, 1973.

16. Singleton VL, Rossi JA. Colorimetry of total phenolics with phosphomolybdicphosphotungstic acid reagents. American journal of Enology and Viticulture. 1965;16(3):144-58.

17. Wrolstad RE, Skrede G, Lea P, Enersen G. Influence of sugaron anthocyanin pigment stability in frozen strawberries. J FoodSci. 1990;55(4):1064-65.

18. Zhishen J, Mengcheng T, Jianming W. The determination of flavonoid contents in mulberry and their scavenging effects on superoxide radicals. Food chemistry. 1999;64(4):555-9.

19. WHO. Quality Control Methods for Medicinal Plant Materials. A.I.T.B.S. Publishers \& Distributors, New Delhi, 2002.

20. Awwad AM, Salem NM, Abdeen AO. Green synthesis of silver nanoparticles using carob leaf extract and its antibacterial activity. International Journal of Industrial Chemistry. 2013;4(1):29.

21. Pimenta AM, Montenegro MC, Araujo AN, Calatayud JM. Application of sequential injection analysis to pharmaceutical analysis. Journal of pharmaceutical and biomedical analysis. 2006;40(1):16-34

22. Gu R, Wang Y, Long B, Kennelly E, Wu S, Liu B, Li P, Long C. Prospecting for bioactive constituents from traditional medicinal plants through ethnobotanical approaches. Biological and Pharmaceutical Bulletin. 2014;37(6):903-15.

23. Saini ML, Ritu Saini, Shikha Roy, Ashwani Kumar. J. Med. Plants Res.2008;2(12):378-86.

24. Cushnie TT, Lamb AJ. Antimicrobial activity of flavonoids. International journal of antimicrobial agents. 2005;26(5):343-56 


\section{GRAPHICAL ABSTRACT}

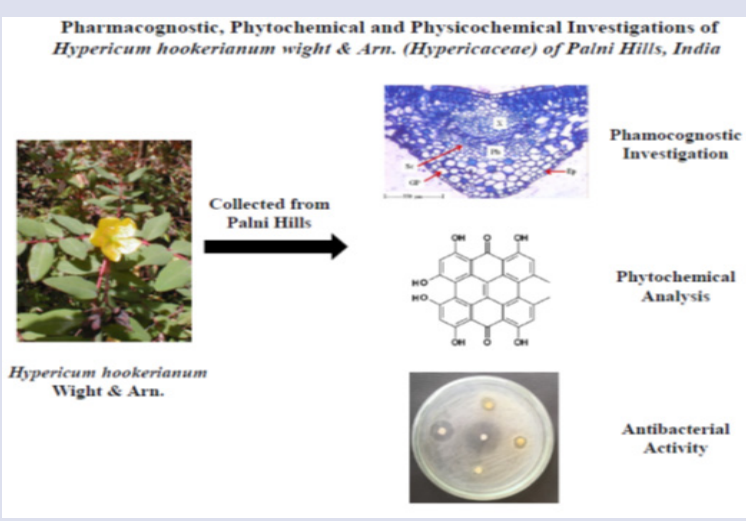

\section{HIGHLIGHTS OF PAPER}

- This is the first study to report the pharmacognostic investigation of Hypericum hookerianum from Palni hills

- The study highlighted the major phytochemicals present in Hypericum hookerianum

- Further exploration of Hypericum hookerianum may reveal many novel products of specialized kind with immense medicinal properties.

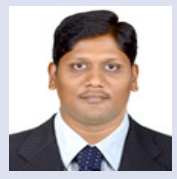

\section{AUTHOR PROFILE}

Mahendrakumar M, a doctoral student at the PG and Research Department of Plant Biology and Plant Biology, Government Arts College for Men, Nandanam, Chennai, Tamil Nadu, India. The doctoral research focused on the scrutiny of traditional plants for their active phytochemical compounds and bioactivity.

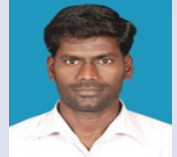

Nirmalraj S, Senior Research Fellow in the Center for Advanced Biological Research, Government Arts College for Men, Nandanam, Chennai, India. His area of interests are ethnobiology and natural products (secondary metabolites) and he has also experienced in pharmacology and pharmacognocy, working in discovery of drug from plants.

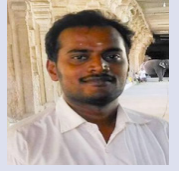

Ravikumar M, doctoral student in Center for Advanced Biological Research, Government Arts College for Men, Nandanam, Chennai, India. His area of interests are Nanotecjhnology, Microbiology and Environmental Biotechnology and he has also experience in environmental monitoring, Water and waste water treatments.

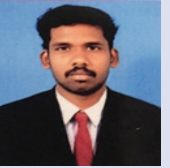

Bharath B, a doctoral student working on algal biotechnology. His interests are isolation of phytocompounds from sea weeds and nanoparticle sysnthesis.

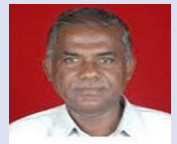

Dr. Seeni S, Director of Research, School of Biosciences, MACFAST, Tiruvalla, Kerala. He has more than 40 years experience in the field of Plant Biotechnology. He has formerly served as the Director of TPGRI, Trivandrum.

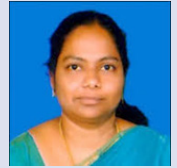

Dr. Perinbam K, Assistant Professor at PG and Research Department of Plant Biology and Plant Biology, Government Arts College for Men, Nandanam, Chennai, Tamil Nadu.

Cite this article : Mahendrakumar M, Nirmalraj S, Ravikumar M, Bharath B, Seeni S, Perinbam K. Pharmacognostic, Phytochemi$\mathrm{cal}$ and Physicochemical Investigations of Hypericum hookerianum Wight \& Arn. (Hypericaceae) of Palni Hills, India. Pharmacog J. 2017;9(6):750-6. 